\title{
Digital teaching skills: comparative study in higher education
}

\section{Habilidades de ensino digital: estudo comparativo no ensino superior}

\section{Habilidades de enseñanza digital: estudio comparativo en educación superior}

\section{Gloria Milagros Torres Molina ${ }^{1}$ (D), Míriam Liliana Flores Coronado ${ }^{2}$ (D) Carlos Fabian Falcon $^{1}$ (D), July Rivera-Zamudio ${ }^{3}$ iD, Luis Alberto Núñez Lira ${ }^{3}$ iD}

\footnotetext{
${ }^{1}$ Universidad César Vallejo, Lima, Perú.

${ }^{2}$ Universidad Nacional Federico Villarreal, Lima, Perú.

${ }^{3}$ Universidad Nacional Mayor de San Marcos. Lima, Perú.

\section{Corresponding author:}

Luis Alberto Núñez Lira

Email: Inunezl@unmsm.edu.pe
}

How to cite: Molina, G. M. T., Coronado, M. L. F., Falcon, C. F., Rivera-Zamudio, J., \& Lira, L. A. N. (2021). Digital teaching skills: comparative study in higher education. Revista Tempos e Espaços em Educação, 14(33), e15527. http://dx.doi.org/10.20952/revtee.v14i33.15527

\begin{abstract}
Research entitled Comparative study of the teacher's digital competencies since the perception of students from four Senati locations, Lima-2020 was intended to establish the significant differences in digital competences between teachers of the different senati headquarters, located in Lima Metropolitana and Callao; the work followed the quantitative methodology, descriptive, comparative and explanatory level; the population was 4440 students with a random sample stratified of 354; the instrument was subjected to the reliability and validity of both content and construct. The main results established that at least two population means are different, as indicated by the $p$ value $(0,000)$ and $F(11,819)$. Lima Cercado's headquarters were also shown to perform better compared to the other headquarters.
\end{abstract}

Keywords: Digital skills. Perception. Teaching. Teaching skills.

\section{RESUMO}

A pesquisa intitulada Estudo comparativo das competências digitais do professor desde a percepção de alunos de quatro localidades do Senati, Lima-2020 teve como objetivo estabelecer as diferenças significativas nas competências digitais entre professores das diferentes sedes senati, localizadas em Lima Metropolitana e Callao; o trabalho seguiu a metodologia quantitativa, descritiva, comparativa e nível explicativo; a população foi de 4440 alunos com uma amostra aleatória estratificada de 354; o instrumento foi submetido à confiabilidade e validade de conteúdo e construto. Os principais resultados estabeleceram que pelo menos duas médias populacionais são 
diferentes, conforme indicado pelo valor de $p(0,000)$ e $F(11.819)$. A sede de Lima Cercado também apresentou um desempenho melhor em comparação com as outras sedes.

Palavras-chave: Ensino. Habilidades de ensino. Habilidades digitais. Percepção.

\section{RESUMEN}

La investigación titulada Estudio comparativo de las competencias digitales del docente desde la percepción de estudiantes de cuatro sedes del Senati, Lima-2020 tuvo como objetivo establecer las diferencias significativas en competencias digitales entre docentes de las distintas sedes del Senati, ubicadas en Lima Metropolitana y Callao; el trabajo siguió la metodología cuantitativa, nivel descriptivo, comparativo y explicativo; la población fue de 4440 estudiantes con una muestra aleatoria estratificada de 354; el instrumento se sometió a la confiabilidad y validez tanto de contenido como de constructo. Los principales resultados establecieron que al menos dos medias poblacionales son diferentes, como lo indican el valor $p(0,000)$ y $F(11,819)$. La sede de Lima Cercado también mostró un mejor desempeño en comparación con las otras sedes.

Palabras clave: Docencia. Habilidades digitales. Habilidades docentes. Percepción.

\section{INTRODUCTION}

Globally, governments have been developing comprehensive strategies and plans for standardization, quality and excellence in teaching throughout the education process from the prekindergarten to the higher level; Over the past 20 years, technology has redesigned the way we work in society, how we communicate, how we learn, and how we teach.

In a digital context, educational institutions face one of the most complicated, fortuitous and difficult times, as globalization implies the possibility and need to seize meaningful opportunities; but also complicated challenges and problems in relation to the future. In this sense, the top-level teacher faces a novel reality where he must have the necessary skills, which will be evident in his teaching sessions. However, few actions related to the use of the computer where teachers are considered right-handed; it is therefore necessary to train highly trained teachers for the management, development of new information and the transmission of such knowledge.

Within the teaching skills, digital competence is fundamental for those who exercise teaching and, in this way, can enhance their classes in a highly digital society; such competence must allow the construction, processing, evaluation and classification of topics taught in a classroom. The term "competence" has been defined as the progressive and dynamic development of skills and/or capacities for the sole purpose of achieving systemic and holistic development throughout life (Tobón, 2008; Lopez, 2014). In this regard, it is appropriate to design appropriate programmes that allow higher education institutions to be convinced that teachers have achieved them; for this reason, the levels of digital skills held by teachers should be specified when they enter their classrooms; from this baseline, adequate teaching can be certified to the current requirements; having the necessary digital skills will help the academic process, accepting that the work environment is currently a highly digital environment; it is then important and necessary for educational institutions to ensure the achievement of these competences in all their teachers, since otherwise we would be facing traditional sessions, behavioural and without the necessary teaching strategies to achieve the desired objectives (Villa \& Poblete, 2007). In addition, a publication was made on the competencies of the teacher observing the particularities of the students and the courses assigned to teachers in the semester; it was concluded that these teachers did not have the necessary profile to develop the established courses (Hirsh, 2014).

Peru is no stranger to this reality, as it still maintains concepts of learnings of yesteryear that, today, are not adequate; these learnings drag students into passive, non-independent and repetitive learning. Unfavourable decision-making in the educational field, focusing on some material aspects and not on human capital which is the most important thing, the lack of teacher 
updating in active methodologies, as well as the lack of notion in the selection and appointment of competent teachers show that many do not have pedagogical training because they come from other professions; much of the classroom teachers are the result of questioned behavioral training. The way of teaching cannot be based on simple repetition or memorization of lessons, the skills and competencies required in the digital age are four: knowing how to search and synthesize information, compare ideas, apply what is found in new situations, as well as create and innovate. In this sense, academic institutions have platforms where the teacher must upload tasks, videoconferences, forums; however, an uns positive condition prevails for these entities: unskilled teachers in digital skills.

This situation has been observed in Senati, a higher technical education institution, which offers more than 30 careers with a teaching population of 2,100 at the Lima-Callao level. In which $60 \%$ of those who teach do not have pedagogical training; there is also a significant percentage of teachers who do not yet have the digital skills needed to teach virtual classes, highlighting monotonous, exhibition and unused classes of technological tools; thus, students are able to observe and make value judgments about their classes and their teachers, their opinions are valued as legitimate, because those students are constantly approaching technologies and can publicize their opinions about the development of their classes with the use of new technologies (Oviedo, 2004).

Therefore, teaching skills are aspects of interest in today's academic world, where institutions establish actions that seek education appropriate to the current context and with highly trained teachers, equipped with technological and didactic tools. Information on this issue needs to be lifted; it is also relevant to analyse this issue and lay the groundwork for further research. Given the considerations set out, the problem arises through the following question: What are the levels of the teacher's digital skills since the perception of students from four Senati locations, Lima-2020?

\section{THEORETICAL FRAMEWORK}

Teacher training schemes focus on student performance and the articulation between student learning and the competence of the student. In this regard, Vasquez (2018) indicated a high level of perception about teaching skills by students, who rate the competence of their teachers as excellent; the students noted that their teachers show a high level of knowledge, attitudes and skills necessary to perform as educators; on the other hand, the positive results also correspond to the perception of responsibility of the university professor. In the same context, Mortis, Valdés, Angulo, García y Cuevas (2015) addressed teachers' perception of their digital competencies with sociolabor, academic and access to technologies; concluded that teachers self-evaluated as good at using technologies and not very good at using methodology, reacting negatively to poor access to the use of technological tools and trainings received; for Perez (2019), the results indicated that teachers have a high level in the use of basic digital tools; but, in advanced-level computing content, they present learning difficulties, a fact that is linked to the non-acquisition of new knowledge in digital resources.

At the same time, studies conducted by Esteban, Laínez, Menjívar, Monroy and Quan (2015), Cardoso, Cerecedo and Ramos (2014) as well as that of Villarreal, García, Hernández and Steffens (2018) concluded that teachers need constant training to improve the development of their classes and make use of computer tools; respondents agreed that their teachers should improve their skills in the use of information technologies, and also require significant support in the management and design of ICT activities as they do not have the tools to develop modern and creative classes.

The studies of Durán, Gutiérrez and Prendes (2016) found a number of common and different elements in the models of digital competences, which included dimensions of the generic concept of digital competence both technical, informational and communicative to which they will incorporate specific ones such as the ability to exploit the educational potential of ICT in the 
teaching processes; in the same line, Gallardo, Minelli, Marqués and Esteve (2015) agreed that digital competence is the sum of skills, knowledge and attitudes not only in technological aspects; but also information, multimedia and application, necessary for teaching staff in higher education, whom the authors call technological multiple literacy.

In addition, Steve (2015) concluded that everyone involved in the educational process is able to handle basic technological tools; there were some shortcomings inthe process of teaching, deficiency in the use of active methodology, and they also presented problems and lack of attitude when using digitaltools; in the same line, Lores, Sánchez and García (2019) found that teachers show a deficit of digital training and that teacher training in technological skills based on information management and participatory learning is urgent. Indeed, the student perspective is valid as learning teaching activities are moderately favourable, because theoretical and practical content is not adequately articulated, as far as academic content is properly articulated, it is clear that teachers do not have a mastery of digital skills, teaching strategies and didactics when it comes to imparting knowledge during their classes (Palomino, 2018).

In this regard, the study of Castellanos, Nieto and Parra (2018) showed that there is minimal mastery in ICT by teachers and students for the benefit of meaningful learning; it was confirmed that there is a separation between reality and what we want to have, between the scheduled and the actual fulfillment of activities; then it is necessary to train teachers when using this instrument, in this way, better results will be achieved. For Casas (2017), there is a high degree of correspondence with the mastery of the assigned subject matter, management, evaluation and use of digital technologies.

From this perspective, the educational work currently demands the need to develop new skills in teachers, considering that these skills enrich the teacher and his work carried out in the classroom in a highly digital environment; therefore, it is crucial for the teacher's performance. Competence in the field of education is acquired on a regular basis and is in permanent progression. Perrenoud (2004) noted that competition is the ability to effectively face countless similar facts, working in an agile, timely manner, making use of various teaching resources in the classroom; For his part, Cano (2008) indicated that it is the cohesion of knowledge, skills and attitudes to carry out executions of the domain, in addition it is contextualized, dynamic and with autonomy.

Teaching competence is understood as a pool of knowledge and skills needed to drive and develop an active and lively class. The student teacher link is the idea strength in teaching activity where you seek to make your mark on students, beyond time. In addition, the teaching competence includes a series of social, cognitive, cultural, affective, labor and productive skills founded on the internal motivations of each person (Labajos, 2014; Ticona, 2014; Torres et al., 2014; Zabalza, 2014)

The definition of digital literacy was raised by Glister (1997) who affirmed the innovative role that technology has played, recognizing the student who is digitally literate as the one who has a set of skills and skills very well related to the management and development of information through networks. Therefore, digital competence is part of the set of competencies that anyone must develop to achieve the goals related to work, employability, learning, inclusion and contribution to society, where the work of the teacher turns out to be important in the development of skills of his students by using strategies in the teaching-learning process and promoting meaningful learning in a digital world.

The insertion of ICTs into the educational process includes considerable growth of new spaces and learning scenarios: semi-presence, remote or online, as well as the development and strengthening of learning with the use of Flipped Classrom, Learning Analytics, Bring Your Own Device, the Internet of Things, big data, augmented reality, programming and robotics (Johnson et al., 2016). Indeed, Adell (2010) considered five dimensions of digital competence: (a) information literacy: it is the ability to work with information so that it can be managed, evaluated, created and communicated to the digital society, (b) technological literacy: we consider the ability to make use 
of digital tools from a cell phone to the most modern devices with skill and skill, (c) multiple literacy: today, we are in a digital age where everything is audiovisual; it is necessary to interpret, communicate, express and create multimedia messages so it is necessary to know how to use audiovisual tools in the teaching career, (d) cognitive competence: which encloses high-level skills such as the analysis, synthesis and evaluation of information as well as the ability to solve problems and (e) digital citizenship: considering that every day changes our way of life, work, relating, etc.; therefore, one must have an ethical, thoughtful and responsible attitude about the use of technologies, know how to be a critical and responsible citizen in the digital field.

For Caccuri (2016), the digital teaching competence is the development of cognitive, procedural and attinal skills that will benefit the realization of both personal and social in a specific environment such as a classroom; to teach in a digital world, it is important to develop digital skills to perform and recognize the new ways in which information circulates; It also sized it into six: (a) information and information literacy: it is based on the ability to ask questions, identify, analyze and discriminate reliable sources of information creatively and ethically, know how to browse Google, Kiddle and Bunis search engines being the last two search engines for children with access to parents and teachers; (b) communication and collaboration: is the ability that shows the suitability to share information through networks, connect with other digital members with ethics and digital awareness, save information in the cloud such as Google Drive, Onedrive with access only for members of a group, use of platforms that allow sharing of information such as Edmodo, Symbaloo, Wetransfer or Mindmeister that allows you to create conceptual maps online; (c) creation of content: it is the apacidad to express yourself through digital written language, produce and program computer content with respect to intellectual property, one of the most used tools are Canva and Genial.ly; (d) security: considers the security and responsible use of information, protection of personal information and individual identity closely related to psychological and social issues; also know the risks and benefits that exist in the use of the Internet; (e) problem solving and critical thinking: today, it takes effect and is considered as the foundations of learning, having the ability to reason in an inductive and deductive way, issuing value juicos, making decisions in complex situations and solving problems creatively and ( $f$ ) pedagogical competencies: it contemplates being able to include ICTs in curriculum design, to the roadmap and apply them through teaching forms , creative and innovative so it is necessary to learn multimedia, hypertextuality, think of the classroom as an open field where technology enriches the teaching process.

In this sense, the overall objective is to determine and compare the levels of the teacher's digital skills from the perception of students from four Senati locations, Lima-2020. The general hypothesis is also determined: There are significant differences in comparing the levels of the teacher's digital skills since the perception of students from four Senati locations, Lima-2020.

\section{METHODOLOGY}

The study was of the applied rate, because it aims to solve a problematic situation of the real context in terms of the deficiencies that exist in the teacher's digital competencies. He knew (2013) that this type of study is intended to provide some alternative solution in a current context of individuals or groups of people and, to do so, has to intervene. It is also comparatively descriptive in nature, because the descriptive data of the digital skills variable of teachers at four Senati locations seen from the perception of students was compared. In this regard, Sánchez y Reyes (2015) indicated that comparative descriptive research details and evaluates in an orderly manner the facts and the parts that make up it in a given time.

The investigative method applied was hypothetical-deductive, because, from the beginning, a hypothesis was raised whose veracity was proven. The design addressed was of the nonexperimental, descriptive comparative, transsectal type, because a single measurement was made at the student level in order to know their perception of the digital skills of their teachers. Kerlinger 
(2002) noted that, in any non-experimental study, variable manipulation is impossible. In addition, transferal since he conducted the survey at any given time.

Sánchez y Reyes (2015) outlined the type of comparative descriptive design for four populations, which is then presented:

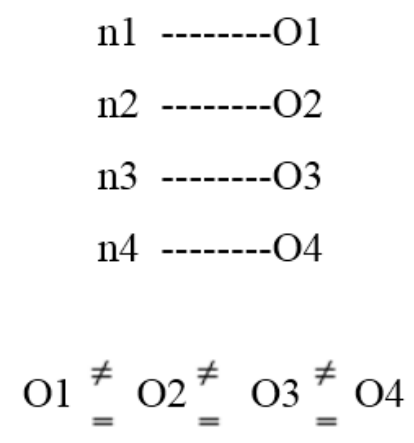

Where: $\mathrm{n}=$ samples; $\mathrm{n} 1$ = sample of the headquarters of Lima Cercado; $\mathrm{n} 2$ = sample of the headquarters of San Juan de Lurigancho; n3 = sample of The Window headquarters; n4 = sample of the headquarters of Villa El Salvador; $\mathrm{O}=$ observation of samples; $\neq=$ symbol of inequality and symbol of equality.

Teacher digital competence is the teacher's ability to generate added value in the courses he teaches; it also creates a meaningful learning environment for students in today's digital age. A 40-item instrument was developed, establishing an ordinal scale in which the variable is quantified for measurement from a Likert, ordinal scale: 5 is Always; 4, Almost always; 3, Sometimes; 2, Almost never and 1, Never.

Table 1. Operationalization of the digital competence variable.

\begin{tabular}{|c|c|c|c|c|}
\hline Dimensions & Indicators & Items & Measuring scale & Levels and ranges \\
\hline $\begin{array}{l}\text { D1: } \\
\text { Information and } \\
\text { information } \\
\text { literacy. }\end{array}$ & $\begin{array}{l}\text { Search. } \\
\text { Evaluation and analysis. } \\
\text { Storage and recovery. } \\
\text { Integration and creation. }\end{array}$ & 1 to 7 & \multirow{6}{*}{$\begin{array}{l}\text { 5: Always } \\
\text { 4: Almost always } \\
\text { 3: Sometimes } \\
\text { 4: Almost never } \\
\text { 1: Never }\end{array}$} & \multirow{6}{*}{$\begin{array}{l}\text { High: } 148-200 \\
\text { Middle: } 94-147 \\
\text { Under: } 40-93\end{array}$} \\
\hline $\begin{array}{l}\text { D2: } \\
\text { Communication } \\
\text { and } \\
\text { collaboration. }\end{array}$ & $\begin{array}{l}\text { Interaction using digital technologies. } \\
\text { Share through digital technologies. } \\
\text { Ethics and citizen participation. } \\
\text { Collaboration. } \\
\text { Digital identity management. }\end{array}$ & 8-15 & & \\
\hline $\begin{array}{l}\text { D3: } \\
\text { Creating } \\
\text { content. }\end{array}$ & $\begin{array}{l}\text { Development of digital content. } \\
\text { Integration of digital content. } \\
\text { Copyright and licensing. } \\
\text { Programming. }\end{array}$ & 16 to 24 & & \\
\hline $\begin{array}{l}\text { D4: } \\
\text { Security. }\end{array}$ & $\begin{array}{l}\text { Protection of devices and digital content. } \\
\text { Protection of personal data and digital } \\
\text { identity. } \\
\text { Health and wellness protection. }\end{array}$ & 25 to 31 & & \\
\hline $\begin{array}{l}\text { D5: } \\
\text { Problem solving } \\
\text { and critical } \\
\text { thinking. }\end{array}$ & $\begin{array}{l}\text { Troubleshooting. } \\
\text { Identification of technological needs and } \\
\text { responses. } \\
\text { Innovation and use of digital technology } \\
\text { creatively. }\end{array}$ & 32 to 34 & & \\
\hline $\begin{array}{l}\text { D6: } \\
\text { Pedagogical } \\
\text { skills. }\end{array}$ & $\begin{array}{l}\text { Planning. } \\
\text { Content development. } \\
\text { Communicate the contents. } \\
\text { Selection. } \\
\text { Value. } \\
\text { Criteria. }\end{array}$ & 35 to 40 & & \\
\hline
\end{tabular}


The population consisted of 4440 students from the four senati headquarters, Lima-2020. In this regard, Carrasco (2017) argued that the population becomes the total of the elements corresponding to the spatial context where the study is to be executed.

Table 2. Study population.

\begin{tabular}{lcccc}
\hline & \multicolumn{3}{c}{ Headquarters } \\
\cline { 2 - 5 } Occupational families & Lima Cercado & $\begin{array}{c}\text { Saint John of } \\
\text { Lurigancho }\end{array}$ & Window & Villa El Salvador \\
\hline Business administration & 650 & 450 & 350 & 160 \\
Graphic arts & 80 & 90 & 160 & 130 \\
Automotive mechanic & 130 & 70 & 90 & 95 \\
Electrical & 80 & 70 & 100 & 95 \\
Food industries & 170 & 130 & 140 & 120 \\
Information technology & 90 & 100 & 140 & 60 \\
Metalworking & 50 & 60 & 70 & 80 \\
Textiles and clothing & 70 & 90 & 110 & 160 \\
Total, by family & 1320 & 1060 & 4440 & \\
Total, population & & & & 900 \\
\hline
\end{tabular}

The exhibition was probabilistic in type and consisted of 1140 students from the four senati headquarters, Lima-2020. On the other hand, the sample is probabilistic when all participants of the population are likely to be randomly appointed (Hernández, Fernández and Baptista, 2014).

To establish the sample of the four senati headquarters, Fisher's formula was applied, for the headquarters of Lima Cercado, which had a population of 1320 students:

$$
n=\frac{Z^{2} \cdot p \cdot q \cdot N}{(N-1) E^{2}+Z^{2} \cdot p \cdot q}
$$

Table 3. Study sample.

\begin{tabular}{lcccc}
\hline & \multicolumn{3}{c}{ Headquarters } \\
\cline { 2 - 4 } Occupational families & Lima Cercado & $\begin{array}{c}\text { San Juan } \\
\text { Lurigancho }\end{array}$ & Window & Villa El Salvador \\
\hline Total per family & 85 & 85 & 92 & 73 \\
Total, shows & \multicolumn{4}{c}{354} \\
\hline
\end{tabular}

Sampling was of a random probabilistic type, i.e. all participants were randomly chosen. For this, random sampling was performed in an Excel file, taking into account the headquarters of Lima Cercado. The same procedure was then continued for the next three locations until sampling was completed. According to Quezada (2015), it consists of the segmentation of the population into groups in which they are understood to be homogeneous in relation to the characteristics to be studied, randomly choosing all the elements that will be part of the sample by random numbers.

The technique was the survey, which has 40 items, distributed in the six dimensions of digital competencies. The instrument was validated by the expert judgment method, which verified the definition of the variable and dimensions, in addition to the indicators, determining their relevance, relevance and clarity, referring to the instrument's measure of what the variable indicates.

Reliable control of the instrument was carried out using the Cronbach Alpha statistic, for which a pilot test was carried out with 45 students surveyed, obtaining a value of 0.829 . Subsequently, the test was performed with the entire sample obtaining a reliability of 0.946 , indicating an excellent level of reliability of the instrument.

For comparative descriptive analysis, it was found that the information obtained from the four Senati headquarters has similar, equal or different levels. In this sense, students were given a 
survey to mark one of the alternatives of the Likert ordinal scale, according to their perception. For the procedure, participants were requested to assist in filling out the survey. Monitoring and control was done for the entire duration of the survey. At the end of the survey, they were thanked for their participation and indicated that an absolute reservation of the recorded data would be kept and that it would only serve the research process.

The normality test was performed to determine whether the data scores came from a normal distribution or not; and with the Anova test the hypotheses for inferential analysis was tested, this test allowed to compare the variance of the four samples of the Senati headquarters in the period 2020.

This investigation respected the rules and procedures established by the institution where it was applied. This applied instrument kept the participants' sense of confidentiality, as codes were used for each participant. The autonomy of the participants was respected, their participation voluntarily opted in, prior to this informed consent was applied. It remains an absolute reserve of the results obtained by each participant; results will also not be taken into account for the evaluation and/or 16-monthly qualification of study subjects. Similarly, the authorship of APA sources and standards was respected.

\section{RESULTS}

\section{Descriptive result}

Analysis of descriptive data on the digital skills of teachers perceived by students in Lima Callao indicated that $13.6 \%$ are in process and $86.4 \%$, in achieved; at Lima Cercado headquarters, $2.4 \%$ are in process and $97.6 \%$ are in progress; at the headquarters of San Juan de Lurigancho, it was observed that $20.0 \%$ is in process and $80.0 \%$, in achieved; at Ventanilla's headquarters, $20.7 \%$ are in process and $79.3 \%$, in achieved and, at the headquarters of Villa El Salvador, $13.7 \%$ are in process and $86.3 \%$, in achieved. The results indicated that the headquarters of Lima Cercado has better results than the other headquarters.

Table 4. Digital competencies in Senati Lima-Callao.

\begin{tabular}{|c|c|c|c|c|c|c|c|c|c|c|}
\hline & \multicolumn{3}{|c|}{$\begin{array}{c}\text { Senati } \\
\text { Lima- Callao }\end{array}$} & \multirow{2}{*}{$\begin{array}{c}\text { Lima Fenced } \\
\text { Headquarters }\end{array}$} & \multicolumn{2}{|c|}{$\begin{array}{c}\text { St. John of } \\
\text { Lurigancho } \\
\text { Headquarters }\end{array}$} & \multicolumn{2}{|c|}{$\begin{array}{c}\text { Window } \\
\text { Headquarters }\end{array}$} & \multicolumn{2}{|c|}{$\begin{array}{l}\text { Headquarters } \\
\text { Villa El Salvador }\end{array}$} \\
\hline & $\mathrm{F}$ & $\%$ & $\mathrm{~F}$ & & $\mathrm{~F}$ & $\%$ & $\mathrm{~F}$ & $\%$ & $\mathrm{~F}$ & $\%$ \\
\hline Home & 0 & 0.0 & 0 & 0.0 & 0 & 0.0 & 0 & 0.0 & 0 & 0.0 \\
\hline Process & 48 & 13.6 & 2 & 2.4 & 17 & 20.0 & 19 & 20.7 & 10 & 13.7 \\
\hline Achieved & 306 & 86.4 & 83 & 97.6 & 68 & 80.0 & 73 & 79.3 & 63 & 86.3 \\
\hline Interest & 0 & 0.0 & 0 & 0.0 & 0 & 0.0 & 0 & 0.0 & 0 & 0.0 \\
\hline Total & 354 & 100.0 & 85 & 100.0 & 85 & 100.0 & 92 & 100.0 & 73 & 100.0 \\
\hline
\end{tabular}

\section{General hypothesis test}

The hypothesis raised used the anova stenographer, presents: $H_{0}$ : .1 .2; $H_{\mathrm{i}}$ : At least two population means are different.

Various samples were established from each location subject to comparison, where the anova $(, 000)$ and $F(11,819)$ test, which is the ratio of the four locations, indicated that the results obtained from the populations under study are different and in addition most of the differences are significant. Thus, Lima Cercado is different with San Juan de Lurigancho (SJL), with Ventanilla - Callao (VC) and Villa El Salvador (VES); they also indicated that the difference in mean in greater between LC and V. In reference to SJL and the other locations, this difference is with LC and the like with VS; in reference to VC, the difference in with $L C$ and the like with SJL and VC; in reference to VES, it is different with LC and similar with the other locations. 
Table 5. General hypothesis test.

\begin{tabular}{|c|c|c|c|c|c|c|c|}
\hline \multicolumn{8}{|c|}{ Multiple comparisons: Teacher's digital competencies } \\
\hline \multirow[b]{2}{*}{ Anova test } & \multirow[b]{2}{*}{ (I) Headquarters } & \multirow[b]{2}{*}{ (J) Headquarters } & \multirow[b]{2}{*}{$\begin{array}{l}\text { Difference in } \\
\text { stockings (I-J) }\end{array}$} & \multirow[b]{2}{*}{$\begin{array}{l}\text { Desv. } \\
\text { Error }\end{array}$} & \multirow[b]{2}{*}{ Gis. } & \multicolumn{2}{|c|}{ 95\% confidence interval } \\
\hline & & & & & & Lower limit & $\begin{array}{l}\text { Upper } \\
\text { limit }\end{array}$ \\
\hline \multirow{6}{*}{$\begin{array}{c}\text { Anova } \\
, 000\end{array}$} & \multirow{3}{*}{ Lima Cercado } & Saint John of Lurigancho & $11,88515^{*}$ & 2,44471 &, 000 & 5,0176 & 18,7527 \\
\hline & & Window - Callao & $11,93810^{*}$ & 2,39276 & ,000 & 5,2165 & 18,6597 \\
\hline & & Villa El Salvador & $10.71587^{*}$ & 2,56378 &, 001 & 3,5139 & 17,9179 \\
\hline & \multirow{3}{*}{$\begin{array}{c}\text { Saint John of } \\
\text { Lurigancho }\end{array}$} & Lima Cercado & $-11,88515^{*}$ & 2,44471 & ,000 & $-18,7527$ & $-5,0176$ \\
\hline & & Window - Callao & 05294 & 2,52080 & 1,000 & $-7,0283$ & 7,1342 \\
\hline & & Villa El Salvador & $-1,16928$ & 2,68367 & ,979 & $-8,7081$ & 6,3695 \\
\hline $\mathrm{F}$ & \multirow{3}{*}{ Window- Callao } & Lima Cercado & $-11,93810^{*}$ & 2,39276 & ,000 & $-18,6597$ & $-5,2165$ \\
\hline \multirow[t]{5}{*}{11,819} & & Saint John of Lurigancho &,- 05294 & 2,52080 & 1,000 & $-7,1342$ & 7,0283 \\
\hline & & Villa El Salvador & $-1,22222$ & 2,63643 & ,975 & $-8,6283$ & 6,1839 \\
\hline & \multirow{3}{*}{ Villa El Salvador } & Lima Cercado & $-10.71587^{*}$ & 2,56378 & ,001 & $-17,9179$ & $-3,5139$ \\
\hline & & Saint John of Lurigancho & 1,16928 & 2,68367 & ,979 & $-6,3695$ & 8,7081 \\
\hline & & Window - Callao & 1,22222 & 2,63643 &, 975 & $-6,1839$ & 8,6283 \\
\hline
\end{tabular}

${ }^{*}$ The difference in means is significant at level 0.05 .

\section{Specific hypothesis test 1}

For this test, various samples were established from each location subject to comparison, where the anova $(, 000)$ and $F(13,688)$ test, which is the ratio of the four locations, indicated that the results obtained from the populations under study are different and in addition most of the differences are significant. Thus, Lima Cercado (LC) is different with SJL, with Ventanilla - Callao and Villa El Salvador; they also indicated that the difference in means is greater in LC with VS. With reference to SJL and the other headquarters, they made no significant difference; in reference to VC, the difference is LC; in reference to VES, it is different with LC and similar with the other locations.

Table 6. Specific hypothesis test 1.

Multiple comparisons: D1: Information and information literacy.

\begin{tabular}{|c|c|c|c|c|c|c|c|}
\hline \multirow[b]{2}{*}{ Anova test } & \multirow[b]{2}{*}{ (I) Headquarters } & \multirow[b]{2}{*}{ (J) Headquarters } & \multirow{2}{*}{$\begin{array}{l}\text { Difference in } \\
\text { stockings (I-J) }\end{array}$} & \multirow{2}{*}{$\begin{array}{l}\text { Desv. } \\
\text { Error }\end{array}$} & \multirow[b]{2}{*}{ Gis. } & \multicolumn{2}{|c|}{ 95\% confidence interval } \\
\hline & & & & & & Lower limit & Upper limit \\
\hline \multirow{6}{*}{$\begin{array}{c}\text { Anova } \\
, 000\end{array}$} & \multirow{3}{*}{ Lima Cercado } & Saint John of Lurigancho & $2,14062^{*}$ & 66634 & 017 & ,2688 & 4,0125 \\
\hline & & Window - Callao & $3,98064^{*}$ & 65218 & ,000 & 2,1486 & 5,8127 \\
\hline & & Villa El Salvador & $3,08571^{*}$ & ,69880 & ,000 & 1,1227 & 5,0487 \\
\hline & \multirow{3}{*}{$\begin{array}{c}\text { Saint John of } \\
\text { Lurigancho }\end{array}$} & Lima Cercado & $-2,14062^{*}$ & 66634 & 017 & $-4,0125$ &,- 2688 \\
\hline & & Window - Callao & 1,84003 & 68708 & 068 &,- 0901 & 3,7701 \\
\hline & & Villa El Salvador & ,94510 & ,73148 & ,644 & $-1,1097$ & 2,9999 \\
\hline $\mathrm{F}$ & \multirow{3}{*}{ Window - Callao } & Lima Cercado & $-3,98064^{*}$ & 65218 & 000 & $-5,8127$ & $-2,1486$ \\
\hline \multirow[t]{5}{*}{13,688} & & Saint John of Lurigancho & $-1,84003$ & 68708 & 068 & $-3,7701$ & ,0901 \\
\hline & & Villa El Salvador &,- 89493 & ,71860 & 671 & $-2,9136$ & 1,1237 \\
\hline & \multirow{3}{*}{ Villa El Salvador } & Lima Cercado & $-3,08571^{*}$ & 69880 & 000 & $-5,0487$ & $-1,1227$ \\
\hline & & Saint John of Lurigancho &,- 94510 & ,73148 & 644 & $-2,9999$ & 1,1097 \\
\hline & & Window - Callao & ,89493 & ,71860 & 671 & $-1,1237$ & 2,9136 \\
\hline
\end{tabular}

${ }^{*}$ The difference in means is significant at level 0.05 .

\section{Specific hypothesis test 2}

For this test, various samples were established from each location subject to comparison, where the anova $(, 000)$ and $F(7,206)$ test, which is the ratio of the four locations, indicated that the results obtained from the populations under study are different and in addition most of the 
differences are significant. Thus, Lima Cercado is different with SJL and Villa El Salvador; they also noted that the average difference is greater between LC and VS. In reference to SJL and other headquarters, it has no significant difference, except LC; in reference to VC, there are no significant differences; in reference to VES, it is different with LC and similar with the other locations.

Table 7. Specific hypothesis test 2.

\begin{tabular}{|c|c|c|c|c|c|c|c|}
\hline \multicolumn{8}{|c|}{ Multiple comparisons: D2: Communication and collaboration. } \\
\hline \multirow[b]{2}{*}{ Anova test } & \multirow[b]{2}{*}{ (I) Headquarters } & \multirow[b]{2}{*}{ (J) Headquarters } & \multirow[b]{2}{*}{$\begin{array}{l}\text { Difference in } \\
\text { stockings (I-J) }\end{array}$} & \multirow[b]{2}{*}{$\begin{array}{l}\text { Desv. } \\
\text { Error }\end{array}$} & \multirow[b]{2}{*}{ Gis. } & \multicolumn{2}{|c|}{ 95\% confidence interval } \\
\hline & & & & & & Lower limit & Upper limit \\
\hline \multirow{6}{*}{$\begin{array}{l}\text { Anova } \\
, 000\end{array}$} & \multirow{3}{*}{ Lima Cercado } & Saint John of Lurigancho & $2,84706^{*}$ & ,75780 & ,003 & ,7183 & 4,9758 \\
\hline & & Window- Callao & 1,22609 & 74170 & ,436 &,- 8575 & 3,3096 \\
\hline & & Villa El Salvador & $3,13611^{*}$ & ,79471 & ,002 & 9037 & 5,3686 \\
\hline & \multirow{3}{*}{$\begin{array}{c}\text { Saint John of } \\
\text { Lurigancho }\end{array}$} & Lima Cercado & $-2,84706^{*}$ & 75780 & ,003 & $-4,9758$ &,- 7183 \\
\hline & & Window- Callao & $-1,62097$ & ,78139 & ,232 & $-3,8160$ & ,5741 \\
\hline & & Villa El Salvador & ,28905 & ,83188 & ,989 & $-2,0478$ & 2,6259 \\
\hline $\mathrm{F}$ & \multirow{3}{*}{ Window- Callao } & Lima Cercado & $-1,22609$ & ,74170 & ,436 & $-3,3096$ & ,8575 \\
\hline \multirow[t]{5}{*}{7,206} & & Saint John of Lurigancho & 1,62097 & 78139 & 232 &,- 5741 & 3,8160 \\
\hline & & Villa El Salvador & 1,91002 & ,81723 & ,143 &,- 3857 & 4,2057 \\
\hline & \multirow{3}{*}{ Villa El Salvador } & Lima Cercado & $-3,13611^{*}$ & 79471 & ,002 & $-5,3686$ &,- 9037 \\
\hline & & Saint John of Lurigancho &,- 28905 & 83188 & 989 & $-2,6259$ & 2,0478 \\
\hline & & Window- Callao & $-1,91002$ & ,81723 & 143 & $-4,2057$ & ,3857 \\
\hline
\end{tabular}

${ }^{*}$ The difference in means is significant at level 0.05 .

\section{Specific hypothesis test 3}

For this test, various samples were established from each headquarters subject to comparison, where the anova $(, 000)$ and $F(10,805)$ test, which is the ratio of the four locations, indicated that the results obtained from the populations under study are different and in addition most of the differences are significant. Thus, Lima Cercado is different with SJL and VC; they also indicated that the difference in means is greater in LC with VC. In reference to SJL and other headquarters, it has no significant difference, except LC; in reference to VC, has no significant difference, except LC; in reference to VES, there are no significant differences.

Table 8. Specific hypothesis test 3.

Multiple comparisons: D3: Creating content

\begin{tabular}{|c|c|c|c|c|c|c|c|}
\hline \multirow[b]{2}{*}{ Anova test } & \multirow[b]{2}{*}{ (I) Headquarters } & \multirow[b]{2}{*}{ (J) Headquarters } & \multirow{2}{*}{$\begin{array}{l}\text { Difference in } \\
\text { stockings (I-J) }\end{array}$} & \multirow{2}{*}{$\begin{array}{l}\text { Desv. } \\
\text { Error }\end{array}$} & \multirow[b]{2}{*}{ Gis. } & \multicolumn{2}{|c|}{ 95\% confidence interval } \\
\hline & & & & & & Lower limit & Upper limit \\
\hline \multirow{6}{*}{$\begin{array}{c}\text { Anova } \\
, 000\end{array}$} & \multirow{3}{*}{ Lima Cercado } & Saint John of Lurigancho & $3,30140^{*}$ & ,73967 & ,000 & 1,2236 & 5,3792 \\
\hline & & Window- Callao & $3,71905^{*}$ & 72395 & ,000 & 1,6854 & 5,7527 \\
\hline & & Villa El Salvador & 1,80238 & ,77569 & 147 &,- 3766 & 3,9814 \\
\hline & \multirow{3}{*}{$\begin{array}{c}\text { Saint John of } \\
\text { Lurigancho }\end{array}$} & Lima Cercado & $-3,30140^{*}$ & ,73967 & 000 & $-5,3792$ & $-1,2236$ \\
\hline & & Window-Callao & ,41765 & ,76269 & 960 & $-1,7248$ & 2,5601 \\
\hline & & Villa El Salvador & $-1,49902$ & 81197 & ,334 & $-3,7799$ & ,7819 \\
\hline $\mathrm{F}$ & \multirow{3}{*}{ Window- Callao } & Lima Cercado & $-3,71905^{*}$ & ,72395 & ,000 & $-5,7527$ & $-1,6854$ \\
\hline \multirow[t]{5}{*}{10,805} & & Saint John of Lurigancho &,- 41765 & ,76269 & ,960 & $-2,5601$ & 1,7248 \\
\hline & & Villa El Salvador & $-1,91667$ & ,79767 & ,125 & $-4,1574$ & ,3241 \\
\hline & \multirow{3}{*}{ Villa El Salvador } & Lima Cercado & $-1,80238$ & ,77569 & 147 & $-3,9814$ & ,3766 \\
\hline & & Saint John of Lurigancho & 1,49902 & 81197 & 334 &,- 7819 & 3,7799 \\
\hline & & Window- Callao & 1,91667 & ,79767 & ,125 &,- 3241 & 4,1574 \\
\hline
\end{tabular}

${ }^{*}$ The difference in means is significant at level 0.05 . 


\section{Specific hypothesis test 4}

For this test, various samples were established from each location subject to comparison, where the anova $(, 000)$ and $F(2,192)$ test, which is the ratio of the four locations, indicated that the results obtained from the populations under study are different and in addition most of the differences are significant. Thus, Lima Cercado there are no significant differences. In reference to SJL and the other headquarters, they do not differ significantly; in reference to VC, it has no significant difference; in reference to VES, there are no significant differences.

Table 9. Specific hypothesis test 4.

\begin{tabular}{|c|c|c|c|c|c|c|c|}
\hline \multicolumn{8}{|c|}{ Multiple comparisons: D4: Security. } \\
\hline \multirow[b]{2}{*}{ Anova test } & \multirow[b]{2}{*}{ (I) Headquarters } & \multirow[b]{2}{*}{ (J) Headquarters } & \multirow{2}{*}{$\begin{array}{l}\text { Difference in } \\
\text { stockings (I-J) }\end{array}$} & \multirow[b]{2}{*}{$\begin{array}{l}\text { Desv. } \\
\text { Error }\end{array}$} & \multirow[b]{2}{*}{ Gis. } & \multicolumn{2}{|c|}{ 95\% confidence interval } \\
\hline & & & & & & Lower limit & Upper limit \\
\hline \multirow{6}{*}{$\begin{array}{l}\text { Anova } \\
, 000\end{array}$} & \multirow{3}{*}{ Lima Cercado } & Saint John of Lurigancho & 77983 & 68461 & ,730 & $-1,1433$ & 2,7030 \\
\hline & & Window - Callao &,- 31863 & 67006 & 973 & $-2,2009$ & 1,5637 \\
\hline & & Villa El Salvador & $-1,11151$ & ,71795 & ,495 & $-3,1283$ & ,9053 \\
\hline & \multirow{3}{*}{$\begin{array}{c}\text { Saint John of } \\
\text { Lurigancho }\end{array}$} & Lima Cercado &,- 77983 & 68461 & 730 & $-2,7030$ & 1,1433 \\
\hline & & Window- Callao & $-1,09847$ & 70592 & 491 & $-3,0815$ & ,8846 \\
\hline & & Villa El Salvador & $-1,89134$ & ,75153 & ,099 & $-4,0025$ & ,2198 \\
\hline $\mathrm{F}$ & & Lima Cercado & ,31863 & 67006 & 973 & $-1,5637$ & 2,2009 \\
\hline \multirow[t]{5}{*}{2,192} & Window - Callao & Saint John of Lurigancho & 1,09847 & 70592 & 491 &,- 8846 & 3,0815 \\
\hline & & Villa El Salvador &,- 79287 & ,73830 & ,764 & $-2,8669$ & 1,2811 \\
\hline & & Lima Cercado & 1,11151 & 71795 & 495 &,- 9053 & 3,1283 \\
\hline & Villa El Salvador & Saint John of Lurigancho & 1,89134 & 75153 & 099 &,- 2198 & 4,0025 \\
\hline & & Window- Callao & ,79287 & ,73830 & ,764 & $-1,2811$ & 2,8669 \\
\hline
\end{tabular}

${ }^{*}$ The difference in means is significant at level 0.05 .

\section{Specific hypothesis test 5}

For this test, various samples were established from each location subject to comparison, where the anova $(, 000)$ and $F(2,091)$ test, which is the ratio of the four locations, indicated that the results obtained from the populations under study are different and in addition most of the differences are significant. Thus, Lima Cercado there are no significant differences. In reference to SIL and the other headquarters, they do not differ significantly; in reference to VC, it has no significant difference; in reference to VES, there are no significant differences.

Table 10. Specific hypothesis test 5.

\begin{tabular}{|c|c|c|c|c|c|c|c|}
\hline \multicolumn{8}{|c|}{ Multiple comparisons: D5: Problem solving and critical thinking } \\
\hline Anova test & (I) Headquarters & (J) Headquarters & $\begin{array}{l}\text { Difference in } \\
\text { stockings (I-J) }\end{array}$ & $\begin{array}{l}\text { Desv. } \\
\text { Error }\end{array}$ & Gis. & $\begin{array}{l}95 \% \text { confide } \\
\text { Lower limit }\end{array}$ & $\begin{array}{l}\text { nce interval } \\
\text { Upper limit } \\
\end{array}$ \\
\hline \multirow{6}{*}{$\begin{array}{l}\text { Anova } \\
\text {,000 }\end{array}$} & \multirow{3}{*}{ Lima Cercado } & Saint John of Lurigancho &,- 21232 & ,38758 & 960 & $-1,3011$ & 8764 \\
\hline & & Window - Callao &,- 28458 & 37934 & ,905 & $-1,3502$ & 7810 \\
\hline & & Villa El Salvador & ,67738 & ,40646 & ,428 &,- 4644 & 1,8192 \\
\hline & \multirow{3}{*}{$\begin{array}{c}\text { Saint John of } \\
\text { Lurigancho }\end{array}$} & Lima Cercado & 21232 & 38758 & 960 &,- 8764 & 1,3011 \\
\hline & & Window- Callao &,- 07225 & 39964 & 998 & $-1,1949$ & 1,0504 \\
\hline & & Villa El Salvador & ,88971 & ,42546 & ,226 &,- 3055 & 2,0849 \\
\hline $\mathrm{F}$ & & Lima Cercado & 28458 & 37934 & ,905 &,- 7810 & 1,3502 \\
\hline \multirow[t]{5}{*}{2,091} & Window- Callao & Saint John of Lurigancho & 07225 & ,39964 & 998 & $-1,0504$ & 1,1949 \\
\hline & & Villa El Salvador & ,96196 & 41797 & 153 &,- 2122 & 2,1361 \\
\hline & & Lima Cercado &,- 67738 & ,40646 & ,428 & $-1,8192$ & ,4644 \\
\hline & Villa El Salvador & Saint John of Lurigancho &,- 88971 & 42546 & ,226 & $-2,0849$ & 3055 \\
\hline & & Window- Callao &,- 96196 & 41797 & 153 & $-2,1361$ & ,2122 \\
\hline
\end{tabular}

${ }^{*}$ The difference in means is significant at level 0.05 . 


\section{Specific hypothesis test 6}

For this test, various samples were established from each headquarters subject to comparison, where the anova $(, 000)$ and $F(18,527)$ test, which is the ratio of the four locations, indicated that the results obtained from the populations under study are different and in addition most of the differences are significant. Thus, Lima Cercado there are significant differences, being greater with VES. In reference to SJL it is different with LC and, with the others, headquarters do not differ significantly; in reference to VC, it has no significant difference; in reference to VS, there are no significant differences.

Table 11. Specific hypothesis test 6.

Multiple comparisons: D6: Pedagogical competencies

\begin{tabular}{|c|c|c|c|c|c|c|c|}
\hline \multirow[b]{2}{*}{ Anova test } & \multirow[b]{2}{*}{ (I) Headquarters } & \multirow[b]{2}{*}{ (J) Headquarters } & \multirow{2}{*}{$\begin{array}{l}\text { Difference in } \\
\text { stockings (I-J) }\end{array}$} & \multirow[b]{2}{*}{$\begin{array}{l}\text { Desv. } \\
\text { Error }\end{array}$} & \multirow[b]{2}{*}{ Gis. } & \multicolumn{2}{|c|}{ 95\% confidence interval } \\
\hline & & & & & & Lower limit & Upper limit \\
\hline \multirow{6}{*}{$\begin{array}{l}\text { Anova } \\
, 000\end{array}$} & \multirow{3}{*}{ Lima Cercado } & Saint John of Lurigancho & $3,02857^{*}$ & ,55661 & 000 & 1,4650 & 4,5922 \\
\hline & & Window- Callao & $3,61553^{*}$ & ,54478 & ,000 & 2,0852 & 5,1459 \\
\hline & & Villa El Salvador & $3,12579^{*}$ & ,58372 & ,000 & 1,4861 & 4,7655 \\
\hline & \multirow{3}{*}{$\begin{array}{l}\text { Saint John of } \\
\text { Lurigancho }\end{array}$} & Lima Cercado & $-3,02857^{*}$ & ,55661 & 000 & $-4,5922$ & $-1,4650$ \\
\hline & & Window- Callao & ,58696 & ,57393 & ,790 & $-1,0253$ & 2,1992 \\
\hline & & Villa El Salvador & 09722 & 61101 & ,999 & $-1,6192$ & 1,8136 \\
\hline $\mathrm{F}$ & \multirow{3}{*}{ Window- Callao } & Lima Cercado & $-3,61553^{*}$ & ,54478 & 000 & $-5,1459$ & $-2,0852$ \\
\hline \multirow[t]{5}{*}{18,527} & & Saint John of Lurigancho &,- 58696 & ,57393 & 790 & $-2,1992$ & 1,0253 \\
\hline & & Villa El Salvador &,- 48973 & ,60026 & ,881 & $-2,1759$ & 1,1965 \\
\hline & \multirow{3}{*}{ Villa El Salvador } & Lima Cercado & $-3,12579^{*}$ & ,58372 & 000 & $-4,7655$ & $-1,4861$ \\
\hline & & Saint John of Lurigancho &,- 09722 & 61101 & ,999 & $-1,8136$ & 1,6192 \\
\hline & & Window- Callao & 48973 & ,60026 & ,881 & $-1,1965$ & 2,1759 \\
\hline
\end{tabular}

${ }^{*}$ The difference in means is significant at level 0.05 .

\section{DISCUSSION}

The contrast of the general hypothesis indicated that at least two population means are different; that is, the existence of differences in e-skills at the four Senati headquarters under study, the results of which showed that the proposed analysis model was relevant where the test explained that the four locations had different results as indicated by $p$ value $(, 000)$ and $F(11,819)$. Lima Cercado's headquarters were also shown to perform better compared to the other headquarters. These results matched those of Vasquez (2018) in that digital competencies have high levels of perception on the part of students; but, unlike the research carried out, this had a better index at LC headquarters; however, for Esteban, Laínez, Menjívar, Monroy and Quan (2015), his studies showed that teachers require constant training to improve their digital skills and make appropriate use of the various ICT tools offered on the networks.

This indicates that the digital skills will enable the proposed pedagogical objectives to be achieved and, in this way, learning, inclusion in the society where the teacher becomes the engine of this process. Thus, both Zahonero and Martín (2012) and López (2014) stated that these competencies allow to carry out with efficiency and autonomy the work entrusted, in addition to accompanying the learning processes. It is important to note that Glister (1997) explained the innovative role of technology, recognizing that the person is digitally literate when he has skills and skills with information management and development across networks. These skills make up digital literacy, building knowledge from other reliable sources and discriminating against its truthfulness, critically analyzing information, examining its validity and integrity.

The contrast of specific hypothesis 1 indicated that at least two population means are different; that is, the existence of differences in digital competences between the four venues, the 
results of which showed that the proposed analysis model was the relevant one where the test explained that the four locations had different results as indicated by $p$ value $(, 000)$ and $F(13,688)$. Lima Cercado's headquarters were also shown to perform better compared to the other headquarters. These results are consistent with those of Mortis, Valdés, Angulo, García and Cuevas (2015) where the digital competencies associated with socio-labor, academic and access to technology variables demonstrate the good use of new technologies; Pérez (2019) also indicated that teachers have a high level in the use of basic digital tools, but, in advanced-level computer content, present learning difficulties, a fact that is linked to the non-acquisition of new knowledge in digital resources. Castellanos, Nieto and Parra (2018) stated that there is minimal mastery in ICT by teachers and students that reduces the development of meaningful learning; confirming that there is a separation between reality and what you want to have, between the scheduled and the actual fulfillment of activities. Thus, to consider yourself digital in a globalized world is to have the sum of skills to make proper use of technological tools and access new information in real time, as well as manage and evaluate resources to build new knowledge.

The contrast of specific hypothesis 2 indicated that at least two population means are different; that is, the existence of differences in teaching digital skills in the four locations, the results of which showed that the proposed analysis model was relevant where the test explained that the four locations had different results as indicated by $p$ value $(, 000)$ and $F(7,206)$. Lima Cercado's headquarters were also shown to perform better compared to the other headquarters. These results are consistent with that of Cardoso, Cerecedo and Ramos (2014) which indicates that teachers are willing to train according to the courses they develop in the academic semester. It should be noted that there is a positive and committed predisposition on the part of teachers to update the face of technological changes. Johnson et al. (2016) noted that the insertion of ICTs into the educational process generates considerable growth of new spaces and learning scenarios.

The contrast of specific hypothesis 3 indicated that at least two population means are different; that is, the existence of differences in teaching digital skills in the four locations, the results of which showed that the proposed analysis model was relevant where the test explained that the four locations had different results as indicated by $p$ value $(, 000)$ and $F(10,805)$. Lima Cercado's headquarters were also shown to perform better compared to the other headquarters. These results consistent with that of Villarreal, García, Hernández and Steffens (2018) which concluded that the use of proven, researched and analyzed patterns is optimal, reinforcing the training of teachers in this area since they require significant support in the management and design of ICT activities since they do not have the necessary tools to develop modern and creative classes. Durán, Gutiérrez and Prendes (2016) also indicated that the digital competence and dimensions of the generic concept of digital competence, both technical, informational and communicative to which, demonstrate the capabilities to exploit the educational potential of ICT in the teaching processes.

For Casas (2017), there is a high degree of correspondence with the mastery of the assigned subject matter, management, evaluation and use of digital technologies. That is where teachers need to develop new skills, considering that these skills enrich the teacher and his work in the classroom in a highly digital environment; therefore, they are basic and necessary for the performance of the teacher.

The contrast of specific hypothesis 4 indicated that at least two population means are different; that is to say, the existence of differences in the digital skills of teachers in the different locations, the results of which showed that the proposed analysis model was the relevant one where the test explained that the four venues had different results as indicated by the $p$ value $(, 000)$ and the $F(2,192)$. It was also demonstrated that, in all four locations, there were no differences in performance compared to the other headquarters. These results consistent with those of Gallardo, Minelli, Marqupes and Esteve (2015) demonstrated that digital skills are the sum of skills, knowledge 
and attitudes, and not only in technological aspects; but also information, multimedia and application, necessary for teaching staff in higher education, whom the authors call technological multiple literacy. In addition, Perrenoud (2004) noted that it is the ability to effectively deal with a number of similar facts, making use of various teaching resources in the classroom. Cano (2008) also indicated that it was the cohesion of knowledge, skills and attitudes in order to carry out executions of the domain; contextualized, dynamic and autonomy.

The contrast of specific hypothesis 5 indicated that at least two population means are different; that is, the existence of differences in digital competences between deocnetes of senati's four headquarters, the results of which showed that the proposed analysis model was relevant where the test explained that the four sites had different results as indicated by $p$ value $(, 000)$ and $\mathrm{F}(2,091)$. It was also demonstrated that, among the four headquarters, there were no differences in performance compared to the other headquarters. These results, consistent with Steve (2015), concluded that everyone involved in the educational process is able to handle basic technological tools; but they presented problems and lack of attitude when using digital tools. However, Lores, Sánchez and García (2019) demonstrated that teachers show a shortfall in digital training and that teacher training in technological skills based on information management and participatory learning is urgently needed.

Torres, Badillo, Valentín and Ramírez (2014) indicated that the teaching competence includes a series of social, cognitive, cultural, affective, labor and productive skills founded on the internal motivations of each person. But, for Caccuri (2016), to be competent is to be able to infer, collate, evaluate and produce new information, which holds the idea of being competent in the development of current issues in the use of ICT.

The contrast of specific hypothesis 6 indicated that at least two population means are different; that is, the existence of differences in digital competences between the teachers of the different locations, the results of which showed that the proposed analysis model was relevant where the test explained that the four venues had different results as indicated by $p$ value $(, 000)$ and $F(18,527)$. It was also shown that there are significant differences in performance compared to other locations. These results were consistent with those of Caccuri (2016) who noted that digital teaching skills for the development of cognitive, procedural and attural skills emphasize that information and information literacy, communication and collaboration, content creation, security and problem solving and critical thinking are fundamental to learning with media development, hypertextuality in the teaching process.

\section{CONCLUSION}

The levels of the teacher's digital skills since the perception of students from four Senati locations, Lima-2020 indicated that at least two population averages are different as indicated by the $p$ value $(, 000)$ and $F(11,819)$. Lima Cercado's headquarters were also shown to perform better compared to the other headquarters.

The levels of information and information literacy of the teacher's digital skills since the perception of students from four Senati locations, Lima-2020 indicated that at least two population averages are different; the test explained that the four locations had different results as indicated by $p$ value $(, 000)$ and $F(13,688)$. Lima Cercado's headquarters were also shown to perform better compared to the other headquarters.

The levels of communication and collaboration of the teacher's digital skills since the perception of students from four Senati headquarters, Lima-2020, indicated that at least two population averages are different, the results of which showed that the proposed analysis model was relevant, as the test explained that the four locations had different results as indicated by the $p$ value $(.000)$ and $F(7,206)$. Lima Cercado's headquarters were also shown to perform better compared to the other headquarters. 
The levels of content creation of the teacher's digital competencies since the perception of students from four Senati headquarters, Lima-2020 indicated that at least two population averages are different, the results of which showed that the proposed analysis model explained that the four locations had different results as indicated by $p$ value $(, 000)$ and $F(10,805)$. Lima Cercado's headquarters were also shown to perform better compared to the other headquarters.

The levels of security of the teacher's digital skills since the perception of students from four Senati headquarters, Lima-2020 indicated that at least two population averages are different, the results of which showed that the analysis model the four locations had different results as indicated by $p$ value $(, 000)$ and $F(2,192)$. It was also shown that, in all four locations, there were no statistically significant differences in performance compared to the other headquarters.

The levels of problem solving and critical thinking of the teacher's digital skills since the perception of students from four Senati headquarters, Lima-2020 indicated that at least two population averages are different, the results of which showed that the four locations had different results as indicated by $p$ value $(, 000)$ and $F(2,091)$. It was also demonstrated that, in all four locations, there were no differences in performance compared to the other headquarters.

The levels of pedagogical skills of the teacher's digital skills since the perception of students from four Senati headquarters, Lima-2020 indicated that at least two population averages are different, the results of which showed that the four locations had different results as noted by $p$ value $(, 000)$ and $F(18,527)$. It was also shown that there are significant differences in performance compared to other locations.

Authors' Contributions: Torres, G. M. T.: conception and design, acquisition of data, analysis and interpretation of data, drafting the article, critical review of important intellectual content; Coronado, M. L. F.: conception and design, acquisition of data, analysis and interpretation of data, drafting the article, critical review of important intellectual content; Falcon, C. F.: conception and design, acquisition of data, analysis and interpretation of data, drafting the article, critical review of important intellectual content; Rivera-Zamudio, J.: conception and design, acquisition of data, analysis and interpretation of data, drafting the article, critical review of important intellectual content; Lira, L. A. N.: conception and design, acquisition of data, analysis and interpretation of data, drafting the article, critical review of important intellectual content. All authors have read and approved the final version of the manuscript.

Ethics Approval: Not applicable.

Acknowledgments: Not applicable.

\section{REFERENCES}

Adell, J. (2010). Las 5 dimensiones de la competencia digital [archivo de video]. Available at: http://www.youtube.com/watch?v:=Vijg83KLOXZs

Brito, R. S., Prado, J. R., \& Nunes, C. P. (2017). As condições de trabalho docente e o pós-estado de bem-estar social. Revista Tempos e Espaços em Educação, 10(23), 165-174. https://doi.org/10.20952/revtee.v10i23.6676

Caccuri, V. (2016). Tecnología digital para docentes: computación y TIC en el aula. Buenos Aires: Fox Andina.

Cano, M. (2008). La evaluación por competencias en la educación superior. Revista de Curriculum y Formación de Profesorado, 12(3).

Cardoso, E., Cerecedo, M. y Ramos, J. (2014). Autoevaluación de las competencias docentes en los posgrados de administración del Instituto Politécnico Nacional. Revista de Estudios y Experiencias en Educacion, 13(25).

Carrasco, S. (2017). Metodología de la Investigación Científica (8 ed.). Lima: San Marcos.

Casas, E. (2017). Competencia docente y aprendizaje autónomo en estudiantes del Instituto de Educación Superior Tecnológico Salesiano de Breña. Lima: Universidad Enrique Guzmán y Valle.

Castellanos, M., Nieto, Z. y Parra, H. (2018). Interpretación de las competencias digitales profesorales presentes en el contexto universitario. Revista Logos, Ciencia \& Tecnología, 10(1). https://doi.org/10.22335/rlct.v10i1.518

Durán, M., Gutiérrez, I. y Prendes, M. (2016). Análisis conceptual de modelos de competencia digital del profesorado universitario. (15, Ed.) Revista latinoamericana de tecnología educativa. http://doi.org/10.17398/1695-288X.15.1.97 
Esteban, R., Laínez, A., Menjívar, S., Monroy, S. y Quan, V. (2015). Competencias docentes del profesorado. Revista de docencia universitaria, 10(2), 103-117.

Gallardo, E., Minelli, J., Marqués, L. y Esteve, F. (2015). Digital competence in the Knowledge society. Joural of Online learning and teaching, 11(1).

Glister, P. (1997). Digital literacy. New York: Wiley Computer Pub.

Hernández, C., Fernández, C. y Baptista, P. (2014). Metodología de la investigación (6 ed.). México D.F.: McGraw Hill. Hirsh, N. (2014). El perfil por competencias del docente de estudios generales de la PUCP. Lima: PUCP.

Johnson, L., Adams, S., Cummins, M., Estrada, V., Freeman, A. y Hall, C. (2016). NMC Informe Horizon 2016 Edición Superior de Educación. Austin, Texas: The New Media consortium.

Kerlinger, F. (2002). Investigación del comportamiento. (1, Ed.) México DF: México: MG Graw Hill.

Labajos, N. (2014). Competencias de los docentes de Enfermería de la UNMSM según percepción de los estudiantes 2013. Lima: Unmsm.

López, A. (2014). Diseño de un protocolo de evaluación de las competencias docentes del profesorado universitario. Cordova: Universidad de Cordova.

Lores, B., Sánchez, P. y García, M. (2019). La formación de la competencia digital en los docentes. Revista de curriculum y formación del profesorado, 23(4).

Mortis, S., Valdés, A., Angulo, J., García, R. y Cuevas, O. (2015). Competencias digitales en docentes de educación secundaria. Municipio de un Estado del Noroeste de México. Perspectiva Educacional, 52(2), 135-153.

Oviedo, L. (2004). La definición del concepto de percepción en psicología con base en la teoría gestalt. Revista de estuidos sociales, $18,89-96$.

Palomino, R. (2018). Percepción de las actividades de enseñanza aprendizaje en los estudiantes durante la especialización en enfermería en una universidad privada de Cusco. Lima: Universidad Peruana Cayetano Heredia.

Pérez, R. (2019). Competencia digital docente en los institutos superiores de formación de maestros: Caso de República Dominicana. Revista de medios y educación, 55(5), 75-97.

Perrenoud, P. (2004). Diez nuevas competencias para enseñar. Barcelona: Graó.

Quezada, N. (2015). Métodología de la investigación. Lima: Macro.

Sánchez, H. y Reyes, C. (2015). Metodología y diseños en la investigación científica. (5, Ed.) Lima: Business Support Aneth SRL.

Steve, F. (2015). La competencia digital docente: análisis y evaluación del desempeño de los estudiantes universitarios de educación por medio de un entorno 3D. Universitat Rovira Vigili.

Silva, L. R., Santos, A. R., \& Santos, I. T. R. (2020). Public policies for education of/in the field and the school environment in a settlement of the MST: the intimate relationship with the pedagogical policy. Journal of Research and Knowledge Spreading, 1(1), e11737.

Supo, J. (2013). Cómo validar un instrumento. LIma, Perú: Bioestadístico EIRL.

Ticona, E. (2014). Evaluación de la gestión académica y competencias docentes en la formación profesional desde la percepción de los estudiantes del décimo semestre de la Facultad de Educación, UNMSM, 2013. Lima: Unmsm.

Tobón, S. (2008). Formación basada en competencias. Madrid: Universidad Complutense de Madrid.

Torres, A., Badillo, M., Valentin, N. y Ramírez, E. (2014). Las competencias docentes: el desafío de la educación superior. Innovación Educativa, 14(66), 129-145.

Vásquez, C. (2018). Percepción sobre las competencias docentes, compromiso académico y actitudes frente a la matemática en Estudiantes de la Universidad de Ciencias y Humanidades. Lima: Universidad Enrique Guzman y Valle.

Villa, A. y Poblete, M. (2007). Aprendizaje basado en competencias. Una propuesta para la evaluación de las competencias genéricas. En Estudios de Educación. Bilbao: Ediciones Mensajero.

Villarreal, S., García, J., Hernández, H. y Steffens, E. (2018). Competencias Docentes y Tranformaciones en la Educación en la Era Digital. La Serena, 12(6). http://dx.doi.org/10.4067/S0718-50062019000600003

Zabalza, M. (2014). Competencias docentes del profesor universitario. Bogotá: Narcea. 
Zahonero, A. y Martín, M. (2012). Formación integral del profesorado: Hacia el desarrollo de competencias personales y de valores en los docentes. Portal de revistas electrónicas UAM Tendencias pedagógicas, 20, 51-70.

Received: 21 January 2021 | Accepted: 12 April 2021 | Published: 25 April 2021

(c) (†)

This is an Open Access article distributed under the terms of the Creative Commons Attribution License, which permits unrestricted use, distribution, and reproduction in any medium, provided the original work is properly cited. 